\title{
Developing Inquiry-Based Learning Materials to Promote Students' Academic Achievement
}

\author{
Hariyanto \\ Postgraduate Program, Science Education Department, Universitas Sebelas \\ Maret Surakarta, Central Java, Indonesia \\ Soetarno Joyoatmojo, Joko Nurkamto and Gunarhadi \\ Faculty of Teacher Training and Education Universitas Sebelas Maret, Surakarta, \\ Central Java, Indonesia
}

\begin{abstract}
The purpose of this study was to develop English learning materials based on Inquiry approach to promote students' academic achievement. The study was a Research and Development. The learning materials were developed by using ADDIE (Analyze, Design, Develop, Implement, and Evaluate) model. It was validated by some experts, such as experts of media, materials, language, and learning design. The result of those validation showed that the English learning materials were very appropriate to be implemented. Data collected through questionnaire. The data of students' academic achievement were taken through written test that was given to 67 students at Midwifery Academy of Harapan Mulya Ponorogo, East Java, Indonesia. They were divided into 35 students in experiment class and 32 students in control class. Data analyzed by using paired $t$ test, and independent sample test. Result of statistical test between pretest and posttest in experimental class showed the significance level was $0.000<0.05$. The result of paired $\mathrm{T}$ test in control class was $0.007<0.05$. The result of independent sample test between experiment and control class showed that the significance level was 0.004 $<0.05$. It can be concluded that inquiry-based learning materials can be a tool to promote students' academic achievement.
\end{abstract}

Keywords: Inquiry learning; learning materials; student achievement; Academic.

\section{Introduction}

Learning is a process to gain new information through interaction of someone with the environment. The information is got through learning process. Instructional is a chain of activities that influence students' behavior. Learning and instructional were two activities that can't be separated. Mayer (2008) stated," Instruction refers to manipulations intended to foster learning. Learning refers to a relatively permanent change in a person's knowledge based on 
experience." Elliott, Kratochwill, Cook, and Travers (2000) confirmed, "Learning is the outcome of an interaction, an interaction between a teacher and a student, two or more students, a student and a computer, a student and a parent, and so on, and is often and active enterprise. Given that learning is an interactive enterprise and often takes place in a classroom, it is desirable to create environments where routine are smooth and efficient, Instruction facilitates personal connection between what is taught and person's prior knowledge, student's attention is maintained and they are frequently asked to act and use information, and material is periodically reviewed and retaught because students learn at different rates and in different ways." Based on the opinion above, it is clearly that interaction in learning process should be improved the instruction should facilitate the students' prior knowledge and what is learnt. Learning materials are also become one of factors that influence students' success in learning, specifically in English learning. El-Omari (2016) said that there are four factors that related to students' English achievement. They are attitudinal, social, socioeconomic, and extracurricular factors. Johnson (2016) in his research found that increasing learning motivation of students were influenced by type of learning materials, content and characteristics of learning materials, individual and group in classroom. The factor that had more positive impact toward students' motivation was content of English learning materials.

Result of preliminary study conducted at Midwifery Academy of Harapan Mulya Ponorogo, East Java, Indonesia by observing teaching and learning process. The learning process indicated the English teacher didn't teach using students centered learning approach, it was conventional teaching that dominated by teacher. The learning materials were also inappropriate with students' need, and core of midwifery knowledge. Result of final examination showed that there were some students who got under standard scores or failed. The condition should be overcome soon. Students' achievement can be promoted by using appropriate teaching method, student-centered learning approach, and appropriate English learning materials.

Inquiry-based learning materials can be one of the solutions. Coffman (2009) defined inquiry based learning as a process in which students involves actively in learning process. Wang, $\mathrm{Wu}, \mathrm{Yu}$, and Lin (2015) said that inquiry based learning was an approach in learning that useful for students in developing higher order thinking. Inquiry-based learning materials of English means the English learning materials based on inquiry learning. It is taught by using inquiry learning approach. The syntax and components of inquiry were involved in the English learning materials.

\section{Theoretical Framework}

Learning materials are materials which are prepared and designed systematically to help teachers in teaching and assisting students to learn. Type of learning materials can be handout, book, module, leaflet, audio, compact disk audio, Computer Assisted Instruction, web based learning, etc. Yaumi (2012) confirmed that learning materials that are developed based on instructional design theory have significant role in creating conducive learning. There are three aspects that make learning materials have important role; 1) the learning 
materials are the representation of teachers' knowledge, 2) As a tool to gain learning objectives, 3 ) the students face directly to the learning materials.

Bocanegra-Valle (2010) defined learning materials in English language," materials are anything which is used to help to teach language learners. Materials can be found in the form of textbook, a workbook, a cassette, a CDroom, a video, a photocopied handout, a newspaper, a paragraph written on a whiteboard, anything which presents or informs about the language being learned." Masuhara and Tomlinson (2008) stated that the learning materials should be informative, able to inform to the students about language. Learning materials should be able to guide students to practice. Learning materials should give experience to the students using the language. Hackbarth (1996) categorized into seven criteria for good written learning materials. They are content, presentation, illustration, supplementary materials, technical features, effectiveness, and overall impression.

The final objective of developing learning materials is students' achievement. Syatriana, Husain, Haryanto and Jabu (2013) in their research found that learning materials and teaching strategies increase students' achievement. The learning result is influenced by some components, one of them is learning materials. Furthermore, they said that the appropriate learning materials will help students' skills completely based on the curriculum. They suggested to the teachers to be creative in developing learning materials.

\section{Inquiry-Based Learning}

Wang, Wu, Yu \& Lin (2015) defined inquiry learning as an approach in learning that provided benefits for students in developing high-level thinking. Nauli (2015) provided understanding that Inquiry based learning was a process where students were involved in learning, formulating questions, investigating deeply, and building new understanding and knowledge. Coffman (2009) Defined Inquiry-based learning was experience, and exploration that involved students in the learning process, in order to gain a deep understanding of what was being taught. Inquiry learning implements a constructivism approach, students interact with the content of the subject matter by asking questions to improve understanding and at the same time construct their knowledge.Kuhlthau, Maniotes, and Caspari (2007) stated some benefits of inquiry based learning for teachers and students. The advantages for students: develop social, language, and reading skill, construct their own meaning, gain independence in research and learning, experience a high level of motivation and engagement, learn strategies and skill transferable to other inquiries project. The advantages of inquiry for teacher, such as share responsibility in the instructional team, share expertise of team member, teach content and information skills simultaneously, experience enhancements of content areas of the curriculum.

Based on the above meanings, it can be concluded that Inquiry-based Learning is a learning approach that involves students actively in learning, through certain stages in order students build their own understanding.

\section{Steps in Inquiry-Based Learning}

The steps in inquiry-based learning according to experts vary. Pedaste, et al. (2015) in their research found 109 different terms in the phase or stage of 
inquiry. Buxton \& Provenzo (2007) proposed an inquiry learning cycle known as the 5E cycle, namely: (1) Engagement stage, teachers introduce subject topics and learning objectives, (2) Exploration stage, students carry out investigations, ask questions, develop hypotheses to be tested, and collect data, (3) Explanation stage, students analyze and interpret data or information collected during exploration, (4) Extension stage, students apply concepts that have been learned for different contexts, (5) Evaluation stage, students summarize the relationship between the variables learned in the lesson and evaluate the results of their work.

\section{English for Specific Purposes (ESP)}

English for Specific Purposes (ESP) is developing because English has been accepted as an international language in the fields of technology and trade, it creates a new generation of learners who know specifically why they are learning languages. Business people who want to sell their products, mechanics that have to be able to read manuals, doctors who want to keep increasing knowledge in their fields of work, and many learners whose subjects are written only in English. All of them need English, they know why they need it.

One of the forms of learning in content-based approaches is the ESP teaching program (Dudley-Evans \& John, 1998); (Hutchinson \& Waters, 1987). The advantages of the ESP program are written materials in English and relevant to the academic program of learners so that the teaching and learning process becomes meaningful and can be a driving force for motivating learning.

Based on the above explanation, the focus of teaching ESP must refer to the purpose of teaching the language that is desired and truly needed by students. The task of the teacher must be able to determine accurately the needs of the students to be formulated in language skills, functions and forms of language in accordance with the needs of students to communicate in various situations. Finally, the benefits of ESP learning both academically and non-academically obtained by students maximally.

\section{Method}

In this section we will reveal the method we used in the study. An overview of research design, participants and data collection procedures, and data analysis.

\section{Research Design}

The research was developmental research study. According to Borg and Gall (1983), "research and development is a process used to develop and validate educational product. The steps of this process are usually referred to as the R \& $\mathrm{D}$ cycle, which consists of studying research findings pertinent to product to be developed, developing the product based on these findings, field testing it in the setting where it will be used eventually, and revising it to correct the deficiencies found in the field testing stage." The cycles of the R \& D according to Borg and Gall (1983) consists of (1) research and collecting information, (2) planning, (3) develop preliminary form of product, (4) preliminary field testing, (5) main product revision, (6) main field testing, (7) Operational product revision, (8) 
operational field testing, (9) final product revision, (10) dissemination and implementation.

The ADDIE model was implemented to develop prototype of English learning materials. The prototype then validated by experts and tested in preliminary field testing, main field testing, and operational field testing.

\section{Sampling and Technique of Sampling}

The respondents of the research were students of midwifery Academy of Harapan Mulya Ponorogo, East Java, Indonesia. There were 67 students that divided into two classes. Experiment class consists of 35 students, and the control class consists of 32 students. The respondents of experiment class were chosen randomly from 40 students, and the respondents of control class were drawn randomly from 37 students.

\section{Data Sources and Collection Procedure}

Data of this study was collected by questionnaire and written test. The Data consisted of the appropriateness of English learning materials for students. In this matter, the learning materials were validated by experts of materials, experts of language, experts of media, and the experts of learning design. The appropriateness of materials consists of content aspects, presentation and inquiry components. The appropriateness of media was measured based on graphics aspects. The appropriateness of language was measured based on its grammar, structure, function and language expression, the appropriateness of learning design was measured based on the components of lesson plan, and syllabus. Students' academic achievement were measured by using English written test that had been tested its validity and normality of the data. The written test was given twice in pretest and posttest for each class.

\section{Data Analysis}

Data analysis in this research was explained as follows;

1) English learning materials based on inquiry were analyzed descriptively. The experts' judgments determined the appropriateness of the learning materials to be implemented in classroom.

2) Students' academic achievement in experiment class and control class were analyzed descriptively.

3) Paired T Test to compare students' academic achievement before and after implementing English learning materials based on inquiry in experiment class;

4) Paired T Test to compare students' academic achievement before and after teaching and learning without using English learning materials based on inquiry.

5) The effectiveness of learning materials was measured by using independent samples statistical, by comparing students' academic achievement in experiment class and control class. 


\section{Result}

\section{The English learning materials based on inquiry}

The result score of experts' validation can be seen as table 1 below:

Table 1: Result of experts' validation

\begin{tabular}{|c|c|c|c|c|c|}
\hline \multirow{2}{*}{ No } & \multirow{2}{*}{ Item Description } & \multicolumn{2}{|c|}{ Experts' Score } & \multirow{2}{*}{ Mean } & \multirow{2}{*}{ Category } \\
\hline & & 1 & 2 & & \\
\hline \multirow[t]{4}{*}{1} & The appropriateness of materials: & & & & \\
\hline & a. Aspects of content & $\begin{array}{c}52 \\
(86.7 \%)\end{array}$ & $\begin{array}{c}52 \\
(86,7 \%)\end{array}$ & $\begin{array}{c}52 \\
(86,7 \%)\end{array}$ & Very good \\
\hline & b. Aspects of presentation & $\begin{array}{c}55 \\
(91,7 \%)\end{array}$ & $\begin{array}{c}54 \\
(90 \%)\end{array}$ & $\begin{array}{c}54,5 \\
(90,8 \%)\end{array}$ & Very good \\
\hline & c. Aspects of inquiry & $\begin{array}{c}25 \\
(89,3 \%)\end{array}$ & $\begin{array}{c}27 \\
(96,4 \%)\end{array}$ & $\begin{array}{c}26 \\
(92,9 \%)\end{array}$ & Very good \\
\hline 2 & The appropriateness of media & $\begin{array}{c}104 \\
(92,9 \%)\end{array}$ & $\begin{array}{c}105 \\
(93,7 \%)\end{array}$ & $\begin{array}{l}104,5 \\
(93,3 \%)\end{array}$ & Very good \\
\hline 3 & The appropriateness of language & $\begin{array}{c}40 \\
(83,3 \%)\end{array}$ & $\begin{array}{c}38 \\
(79,1 \%)\end{array}$ & $\begin{array}{c}39 \\
(81,2 \%)\end{array}$ & Very good \\
\hline 4 & $\begin{array}{l}\text { The appropriateness of learning } \\
\text { design }\end{array}$ & $\begin{array}{c}80 \\
(90,9 \%)\end{array}$ & $\begin{array}{c}82 \\
(93,2 \%)\end{array}$ & $\begin{array}{c}81,5 \\
(92,6 \%)\end{array}$ & Very good \\
\hline
\end{tabular}

Table 1 indicates that all of aspects have very good category. The result implies that the English learning materials based on inquiry is very appropriate and can be used in teaching and learning process.

\section{Students' Academic Achievement}

The following tables are the results of pretest conducted to the students in experiment class and control class.

Table 2: Students pretest result in experiment class

\section{Descriptive Statistics}

\begin{tabular}{cccccc}
\hline & $\mathrm{N}$ & Minimum & Maximum & Mean & Std. Deviation \\
\hline Pretest_experiment & 35 & 37.80 & 84.40 & 63.9971 & 8.52641 \\
Valid N (listwise) & 35 & & & & \\
\hline
\end{tabular}

Table 3: Students' pretest result in control class

Descriptive Statistics

\begin{tabular}{lrrrrr}
\hline & N & Minimum & Maximum & Mean & Std. Deviation \\
\hline Pretest_Control & 32 & 28.90 & 77.80 & 58.8219 & 11.48108 \\
Valid N (listwise) & 32 & & & & \\
\hline
\end{tabular}

Based on table 2, it shows that there are 35 students as respondents. The minimum score of English written test is 37, 8 and the maximum is 84. 4, mean of score is 63,99 . Table 3 showed that the respondents are 32 students. Minimum score in control class is 28,8 and the maximum score is 77,8 , mean of score is 58 , 82. 
Table 4: Students' posttest result in experiment class

\begin{tabular}{lrrrrr}
\multicolumn{7}{c}{ Descriptive Statistics } \\
\hline & N & Minimum & Maximum & Mean & Std. Deviation \\
Posttest_eksperiment & 35 & 48.90 & 84.40 & 72.6314 & 7.65233 \\
Valid N (listwise) & 35 & & & & \\
\hline
\end{tabular}

Table 5: Students' posttest result in control class

\begin{tabular}{lrrrlr}
\multicolumn{7}{c}{ Descriptive Statistics } \\
\hline Postest_control & 32 & 44.40 & 86.70 & 65.8312 & 10.47059 \\
Valid N (listwise) & 32 & & & & \\
\hline
\end{tabular}

Table 4 indicates that minimum score in experiment class is 48,9 and the maximum score is 84,4 . Mean score is 72,63 . Table 5 shows that minimum score in control class is 44,4 and the maximum score is 86,7 mean of score is 65,83 .

\section{Students' Academic Achievement Different before and after Implementing English Learning Materials Based on Inquiry}

The following table is paired $t$ test to measure the difference of students' academic achievement in experiment class.

Table 6: The difference of students' academic achievement in experiment class

\begin{tabular}{llllrc}
\multicolumn{6}{c}{ Paired Samples Statistics } \\
\hline & & & Std. & Std. Error \\
& & Mean & N & Deviation & Mean \\
\hline Pair 1 & Pretest_experiment & 63.9971 & 35 & 8.52641 & 1.44123 \\
& Posttest_experiment & 72.6314 & 35 & 7.65233 & 1.29348 \\
\hline
\end{tabular}

Table 6 shows that there is difference of score in posttest and pretest. Students' academic achievement from posttest is higher than pretest. Score of posttest is 72,63 and the score of pretest is 63,99.

Table 7: Result of paired sample test in experiment class

\begin{tabular}{|c|c|c|c|c|c|c|c|c|c|}
\hline \multicolumn{10}{|c|}{ Paired Samples Test } \\
\hline & & \multicolumn{5}{|c|}{ Paired Differences } & \multirow[b]{3}{*}{$\mathrm{t}$} & \multirow[b]{3}{*}{$\mathrm{df}$} & \multirow{3}{*}{$\begin{array}{l}\text { Sig. (2- } \\
\text { tailed) }\end{array}$} \\
\hline & & \multirow[b]{2}{*}{ Mean } & \multirow{2}{*}{$\begin{array}{c}\text { Std. } \\
\text { Deviation }\end{array}$} & \multirow{2}{*}{$\begin{array}{l}\text { Std. Error } \\
\text { Mean }\end{array}$} & \multicolumn{2}{|c|}{$\begin{array}{l}\text { 95\% Confidence } \\
\text { Interval of the } \\
\text { Difference }\end{array}$} & & & \\
\hline & & & & & Lower & Upper & & & \\
\hline Pair 1 & $\begin{array}{l}\text { Pretest_experiment - } \\
\text { Posttest_experiment }\end{array}$ & -8.63429 & 9.93245 & 1.67889 & -12.04620 & -5.22237 & -5.143 & 34 & .000 \\
\hline
\end{tabular}

Table 7 above shows the result of paired samples test. The significance level was $0.000<0.05$. It means there is significant different of students' academic achievement after implementing English learning materials based on inquiry. 


\section{Students' Academic Achievement Different in Control Class}

The table below shows the different of students' academic achievement in control class where the teacher didn't use English learning materials based on inquiry.

Table 8: Result of students' academic achievement in control class

Paired Samples Statistics

\begin{tabular}{llrrrc}
\hline & & & \multicolumn{2}{c}{ Std. } & Std. Error \\
& & Mean & N & Deviation & \multicolumn{1}{c}{ Mean } \\
\hline Pair 1 & Pretest_control & 58.8219 & 32 & 11.48108 & 2.02959 \\
& Postest_control & 65.8313 & 32 & 10.47059 & 1.85096 \\
\hline
\end{tabular}

Table 8 indicates mean score of pretest in control class is 58,82 with standard deviation is 11,48 , mean score of posttest in control class is 65,83 with standard deviation 10,47 .

Table 9: Result of paired sample test in control class

Paired Samples Test

\begin{tabular}{|c|c|c|c|c|c|c|c|c|c|}
\hline & & \multicolumn{5}{|c|}{ Paired Differences } & \multirow[b]{3}{*}{$\mathrm{t}$} & \multirow[b]{3}{*}{$\mathrm{df}$} & \multirow{3}{*}{$\begin{array}{l}\text { Sig. (2- } \\
\text { tailed) }\end{array}$} \\
\hline & & \multirow[b]{2}{*}{ Mean } & \multirow{2}{*}{$\begin{array}{c}\text { Std. } \\
\text { Deviation }\end{array}$} & \multirow{2}{*}{$\begin{array}{l}\text { Std. Error } \\
\text { Mean }\end{array}$} & \multicolumn{2}{|c|}{$\begin{array}{l}\text { 95\% Confidence Interval } \\
\text { of the Difference }\end{array}$} & & & \\
\hline & & & & & Lower & Upper & & & \\
\hline $\begin{array}{l}\text { Pair } \\
1\end{array}$ & $\begin{array}{l}\text { Pretest_control - } \\
\text { Postest_control }\end{array}$ & -7.00938 & 13.66154 & 2.41504 & -11.93489 & -2.08386 & -2.902 & 31 & .007 \\
\hline
\end{tabular}

Table 9 shows paired sample test, the significance level is $0,007<0,05$. It means there is significant different of students' academic achievement in control class.

\section{The effectiveness of English Learning Materials based on Inquiry}

The independent sample test is used to measure the effectiveness of the learning materials. The score of posttest in experiment class are compared with the score of posttest in control class. The result is shown as below:

Table 10: Result of comparing posttest score between experiment and control class

\begin{tabular}{llrlrr}
\hline & Group & N & Mean & Std. Deviation & Std. Error Mean \\
Score Post_English & Experiment & 35 & 72.6314 & 7.65233 & 1.29348 \\
& control & 32 & 65.8313 & 10.47059 & 1.85096 \\
\hline
\end{tabular}

Table 10 indicates that there is different score between experiment class and control class. Mean of score in experiment class is 72, 63, and mean of score in control class is 65,83 . The experiment class has higher score than control class.

The Independent sample test measures the different of score between groups as below. 
Table 11: Statistical analysis of independent samples test in experiment and control class.

\begin{tabular}{|c|c|c|c|c|c|c|c|c|c|c|}
\hline \multicolumn{11}{|c|}{ Independent Samples Test } \\
\hline & & $\begin{array}{r}\text { Levene' } \\
\text { for Equa } \\
\text { Variar } \\
\end{array}$ & $\begin{array}{l}\text { Test } \\
\text { ty of } \\
\text { es } \\
\end{array}$ & \multicolumn{7}{|c|}{ t-test for Equality of Means } \\
\hline & & \multirow[t]{2}{*}{$\mathrm{F}$} & \multirow[t]{2}{*}{ Sig. } & \multirow[t]{2}{*}{$\mathrm{t}$} & \multirow[t]{2}{*}{ df } & \multirow[t]{2}{*}{$\begin{array}{l}\text { Sig. (2- } \\
\text { tailed) }\end{array}$} & \multirow{2}{*}{$\begin{array}{c}\text { Mean } \\
\text { Differenc } \\
\mathrm{e}\end{array}$} & \multirow[t]{2}{*}{$\begin{array}{l}\text { Std. Error } \\
\text { Difference }\end{array}$} & \multicolumn{2}{|c|}{$\begin{array}{l}95 \% \text { Confidence } \\
\text { Interval of the } \\
\text { Difference }\end{array}$} \\
\hline & & & & & & & & & Lower & Upper \\
\hline \multirow[t]{2}{*}{$\begin{array}{l}\text { Score_Posttest } \\
\text { English }\end{array}$} & $\begin{array}{l}\text { Equal variances } \\
\text { assumed }\end{array}$ & 2.618 & .111 & 3.053 & 65 & .003 & 6.80018 & 2.22715 & 2.35225 & 11.24811 \\
\hline & $\begin{array}{l}\text { Equal variances not } \\
\text { assumed }\end{array}$ & & & 3.011 & 56.406 & .004 & 6.80018 & 2.25812 & 2.27733 & 11.32303 \\
\hline
\end{tabular}

Table 11 indicates that the significance level is $0.004<0,05$. It means that there is significance difference of students' academic achievement between posttest in experiment class and control class. It implies that the English learning materials based on inquiry is effective to be implemented in teaching and learning process. The English learning materials based on inquiry promotes students' academic achievement.

\section{Discussion}

English learning materials based on inquiry gives wide opportunity for the students to explore their previous experience and combining with new knowledge they have learnt. This is the core of constructivism. Kuhlthau et al. (2007) said, "one of the basic tenets of constructivist theory is that past experience and prior understanding form the basis for constructing new knowledge." Coffman (2009) said that new understanding construction of knowledge was begun with essential questions, finding, exploring, and disseminating the findings. The process will make students involve actively in learning process.

Developing English learning materials based on inquiry by development design of ADDIE because it is an effective model to produce some educational products. "Creating products using an ADDIE process remains one of today's most effective tools. Because ADDIE is merely a process that serves as a guiding framework for complex situations, it is appropriate for developing educational products and other learning resources" (Branch, 2009). ADDIE is an acronym for Analyze, Design, Develop, Implement, and Evaluate. Analyze purposes to identify the probable causes for a performance gap, Design purposes to verify the desired performances and appropriate testing methods, Implement purposes to Prepare the learning environment and engage the students, and evaluate purposes to assess the quality of the instructional products and processes, both before and after implementation.

Table 1 shows that the English learning materials have been validated by experts. The result of validation is very good category, and it can be implemented to the students. The result implies that the learning materials are written based on the need analysis of students. Needs analysis is a process which is undertaken by trainers, teachers and course designers to ascertain the pre-requisites for developing a course along with its plan implementation. Nunan (1989) stated that techniques and procedures for collecting Information 
to be used in syllabus design are referred to as needs analysis. Liton (2015) suggested that English learning materials specifically English for Specific Purposes materials should be appropriate with students' need and communication skill in workplace. The needs perception held by students indicates that students realize that English was very important and needed to be much improved to help with employment advantage or future job performance (Lee, 2016).

Based on table 2 and table 3, It indicates that pretest score between experiment class and control class are different. The score of students in experiment class are higher than control class. Table 4 and table 5 show that the mean score of students in experiment class are higher than control class. There are some factors affecting students' achievement. Supasorn and Lordkan (2014) in their research concluded that implementation of learning activity based on inquiry was an effective to promote students' achievement and attitude. Sabarun (2016) recommended that the students apply inquiry-based learning when studying TOEFL.

Implementation of English learning materials based on inquiry in experiment class has positive impact to promote students' academic achievement. The findings are supported by statistical analysis result as shown in table 6 and table 7. There's significant different of students' academic achievement before and after implementing the English learning materials. The effectiveness of English learning materials can be seen from the result independent sample test as shown at table 10 and table 11 . The significance level is $0.004<0.05$. It means $\mathrm{H} 0$ is rejected, There is significant different between students' academic achievement before and after implementing English learning materials based on inquiry. The learning materials have positive impact to promote students' academic achievement.

\section{Implications}

Developing English learning materials based on inquiry implicates to learning activity. Teacher should change the teaching approach to become studentcentered learning. The students must involve actively in learning process. The role of teacher in the classroom is a facilitator, and motivator to create joyful learning.

\section{Conclusion}

English learning materials based on inquiry is developed by using instructional design of ADDIE. The model produces English learning materials based on inquiry which is validated by experts of material, language, media and learning design. According to the experts, the English learning materials based on inquiry have very good category. It can be implemented to the classroom for teaching and learning process. The English learning materials are tested statistically by using paired samples test and independent samples test. The result of statistical $t$ test confirmed that English learning materials based on inquiry were effective to promote students' achievement. 


\section{Acknowledgement}

The present study and the conducted research have been supported by Midwifery Academy of Harapan Mulya Ponorogo, East Java, Indonesia. Our gratitude also extends to our teacher at Universitas Sebelas Maret of Surakarta, Central Java, Indonesia. We thank to our colleagues from Universitas Sebelas Maret of Surakarta, Central Java, Indonesia who provided insight that greatly assisted the research.

\section{References}

Bocanegra-Valle, A. (2010). Evaluating and designing materials for the ESP classroom. In M. F. Ruiz-Garrido, J. C. Palmer-Silveria\& I. Fortanet-Gomez (Eds.), English for professional and academic purposes. New York: Editions Rodopi.

Borg, W. R., \& Gall, M. D. (1983). Educational research: An introduction (Fourth ed.). New York: Longman Inc.

Branch, R. M. (2009). Instructional Design: The ADDIE approach. London: Springer Science. https://doi.org/10.1007/978-0-387-09506-6_3.

Buxton, A. C., \& Provenzo, E. F. ( 2007). Teaching science in elementary and middle school. New York: SAGE Publication. https://doi.org/10.4324/9780203113660.

Coffman, T. (2009). Engaging students through inquiry-oriented learning and technology. New York: Rowman \& Littlefield Education.

Dudley-Evans, \& John, S. (1998). Developments in English for specific purposes: A multidisciplinary approach. Cambridge: Cambridge University Press. https://doi.org/10.1016/s0889-4906(99)00026-5.

El-Omari, A. H. (2016). Factors affecting students' achievement in English language learning. Journal of Educational and Social Research, 6(2), 9-17. https://doi.org/10.5901/jesr.2016.v6n2p9 Elliott, S. N., Kratochwill, T. R., Cook, J. L., \& Travers, J. F. (2000). Educational pychology: Effective teaching, effective learning (Third ed.). New York: McGraw Hill Companies.

Hackbarth, S. (1996). The Educational technology handbook: A comprehensive guide: Process and products for learning. Englewood Cliffs: Educational technology Publications.

Hutchinson, T., \& Waters, A. (1987). English for specific purposes. Cambridge: Cambridge University Press.

Johnson, M. (2016). A Qualitative examination of ESP instructional materials and motivational engagement. ESP Today, 3(1), 83-96.

Kuhlthau, C. C., Maniotes, L. K., \& Caspari, A. K. (2007). Guided inquiry learning in the 21st century. London: Library Unlimited.

Lee, C.-L. (2016). Principles and practices of ESP course design- A case study of a university of science and technology. International Journal of Learning, Teaching and Educational Research, 15(2), 94-105.

Liton, H. A. (2015). ESP learners' needs related learning for the workplace: A pragmatic study for business school. International Journal of Instruction, 8(2), 3-15. https://doi.org/10.12973/iji.2015.821a.

Masuhara, H., \& Tomlinson, B. (2008). Materials for general English. In B. Tomlinson (Ed.), English language learning materials: A critical review. London: Continuum International Publishing Groups. https:/ / doi.org/10.5040/9781474212182

Mayer, R. E. (2008). Leaning and insruction (2nd ed.). New Jersey: Pearson Merill Prentice Hall.

Nauli, B. S. (2015). Combining inquiry, learning community and total physical response for teaching English. English Education Journal (EEJ), 6(3), 356-369.

Nunan, D. (1989). Designing task for the communicative classroom. Cambridge: Cambridge University Press. 
Pedaste, M., Maeots, M., Siiman, L. A., Jong, T. d., Riesen, S. A. N. V., Kemp, E. T., Tsourlidaki, E. (2015). Phases of inquiry-based learning: Definition and the inquiry cycle. Educational Research review, 2015(14), 47-61.

https://doi.org/10.1016/j.edurev.2015.02.003

Sabarun. (2016). The effect of inquiry-based learning on students' institutional Toefl score at English department of IAIN Palangkaraya. Paper presented at the National Conference on English Language Teaching (NACELT), Palangkaraya.

Supasorn, S., \& Lordkan, A. (2014). Enhancement of grade 7 students learning achievement of the matter separation by using inquiry learning activities. Procedia Social and Behavioral Sciences, 2014(116), 739-743. https://doi.org/10.1016/j.sbspro.2014.01.290

Syatriana, E., Husain, D., Haryanto, \& Jabu, B. (2013). A model of creating instructional materials based on the school curriculum for Indonesian secondary schools. Journal of Education and Practice, 4(20), 10-18. https://doi.org/10.31219/osf.io/z8gf9

Wang, P. H., Wu, P. L., Yu, K. W., \& Lin, Y. X. (2015). Influence of implementing inquirybased instruction on science learning motivation and interest: A perspective of comparison. Procedia Social and Behavioral Sciences, 174(2015), 1292-1299. https://doi.org/10.1016/j.sbspro.2015.01.750

Yaumi, M. (2012). Pengembangan bahan ajar English for specific purpose berbasis TIK. Lentera Pendidikan, 15(2), 144-160. . https://doi.org/10.24252/lp.2012v15n2a2 